\title{
Recruitment into the Nigerian Federal Public Service: \\ Constraints and Agenda for Reform
}

\author{
Ademola Pius Adebisi, Ph.D(Corresponding author) \\ Adjunct Lecturer, Department of Political Science, \\ Joseph Ayo Babalola University, \\ Ikeji- Arakeji, Osun State. \\ Email: adebisi_pius@yahoo.com
}

Received: Nov. 20, 2017 Accepted: Oct. 18, 2017 Online published: Oct. 28, 2017

doi:10.5296/jpag.v7i4.12077～URL: https://doi.org/10.5296/ jpag.v7i4.12077

\begin{abstract}
It has been observed that the Nigerian Federal Public Service has been bedeviled by over blotedness, low productivity, ineffectiveness, cronism and manpower lopsidedness. These challenges have been traced to the flawed recruitment into the service. This research work investigated the recruitment process into the Nigerian public service using primary and secondary sources of data and the Federal public service as a case study and discovered that, both exogenous and endogenous social pressures have been the banes of recruitment into the Nigerian Federal Public Service. The study therefore proposed an agenda for reform which among others include: re-orientation of public officials handling recruitment process; establishment of Bureau of Employment Monitoring (BEMO) to perform oversight function over recruitment process; sanctioning of erring government officials handling recruitment into the service and reforming the Nigerian economy with a view to stimulating more jobs in the private sector and thereby reducing the social pressures on public service jobs.
\end{abstract}

Keywords: public service, nigerian public service, recruitment, constraints, agenda for reform

\section{Introduction}

The public service of every modern state is the fulcrum upon which governmental policies and public services are dispensed to the citizenry. To many scholars, political leaders and public administration practioners, the public service is an indispensable sub-governmental machinery of every modern state. This is also on the account of the fact that it is the instrumentality by which governmental policies are partly formulated. Writing on the experience of the United States of America, Denhardt and Denhardt (2009) pointedly 
submitted that, throughout most of our country's history, public service has been recognized as an important undertaking that contributes to the betterment of society. In the context of governance in Nigeria, Akande(2014) wrote that: the civil service is central to the performance of any government, it constitutes the tool for the formulation and implementation of an administration's policies and programs. This assertion about the core civil service, which is a slice of the public service is equally true and correct of the wider spectrum of the public service, nay the Nigerian Federal Public Service (Adebisi, 2014). For a public service to be able to play this vital role of facilitator or driver of governmental processes, it must be powered by competent hands and in a federal and heterogeneous state like Nigeria, it must also take into consideration, in the recruitment process, the diverse character of the state without loosing its unity of purpose. As Denhardt and Denhardt (2009) have again observed of the USA, the need for a strong public service is growing, not lessening. This is equally true of Nigeria. It is therefore imperative as Max Weber has pinpointed many years ago in his analysis of bureaucracy, that, while it may be hard for a state to absolutely discount other social environmental influences in the process of recruiting its bureaucracy, premium must still be placed on merit and competence. In addition to this, most modern states particularly the federal ones, have come to the realization also that, recruitment efforts in the public sector must also be concerned with assuring fairness, openness and representativeness. It is in realization of this that the Nigerian state has not only provided room for recruiting competent people into the service, but has also instituted administrative structures to foster transparency and ensure the reflection of the federal character of the country in the process of recruiting into the public service.

However, it has been observed that most of the rules and procedures put in place to ensure that the principles of competence, fairness, openness and representativeness are guaranteed are honoured more in the breach than the observance as incompetent hands have been finding their ways into the service through the backdoor. Lamenting these trends in the Nigerian Federal public service, the Unemployed Graduates Association of Nigeria; Association of Nigerian Graduates Against Unemployment and the Youths Arise Against Unemployment and Poverty, had in a petition, alleged that:

Under the government several agencies have engaged in secret recruitments of employees as against advertising vacancies in line with the provisions of the law and Federal character... They had enlisted... candidates who are relatives, wards, and protégés of politicians and influential personalities... into the service (The Punch Newspaper, 2017).

Generally speaking and more specifically, some of the common recruitment malpractices are as summed as follows: Recruitment without advertisement.

(1) Outright sale of jobs by syndicate groups in the Civil Service Commission and other agencies.

(2) Employment of people with higher qualifications into lower cadres with the intention of bringing in the candidates into the establishments having been assessed unqualified for higher grades or that vacancies do not exist for higher grades. 


\section{MInstitute Macrothink}

Journal of Public Administration and Governance

ISSN 2161-7104

2017, Vol. 7, No. 4

(3) Recruitment without facing the rigors of written or oral examination as required by the scheme of service.

(4) Employment of overage persons into permanent positions through manipulation of date of birth.

(5) Employment of indigenes of the local government, the state or the town/village of the Head or Chief Executive of an establishment in large number into an establishment.

(6) Employment of the family members of the workers in an establishment into positions within the organization.

(7) Employment of persons with irrelevant qualifications like employing a graduate of Education or Forestry as Administrative Officer where the Scheme of service requires graduates of Arts and Social Sciences.

(8) Employment of persons with lower qualifications such as employing someone with Second Class Lower degree as Assistant Lecturer when the Scheme of Service requires Second Class Upper degree.

(9) Employment of persons into wrong positions such as when a University graduate with Third Class degree in Agriculture is employed as a Technologist because he could not fit into Lecturer cadre where a minimum of Second Class Upper is required, and whereas only holders of Higher National Diploma are supposed to be engaged as Technologists according to the establishment's scheme of service.

Employment in disregard of actual manpower needs (Adetula, J.O, Ijatuyi, D. \& Abbas A.\& Popoola, A. personal communications, $6^{\text {th }}$ January,2007- $20^{\text {th }}$ May, 2017).

The major consequences of all these are the following: one, it has engendered low productivity in the public service. Two, it has also generated ineffectiveness and inefficiency in the service as incompetent staff abound in many federal public service organizations hence poor service delivery. Three, as a result of these developments also, the service is no longer endowed with good officers who can communicate very well in writing including writing official letters, report writing, writing of memoranda and good speeches among others. Four, it has deprived the public service of critical minds that are capable of critical analysis required in the processes of policy formulation and policy analysis. Against the above backdrop therefore, this article seeks to achieve the following specific objectives:

(a) To identify the major forces or factors constraining the process of recruitment into the public service in Nigeria.

(b) To evolve framework by which greater fairness, openness, representativeness and merit can be fostered in the process of recruitment into the public service in Nigeria.

\section{Scope of the Study}

Nigeria is a federation with three tiers of government, namely federal, state and local governments. Each level of government has its own service. This study, however, focuses 
only on the federal public service.

\section{Methodology}

This study relied on both primary and secondary sources of data; and the data analysis technique is wholely qualitative. The main primary sources of data were interview and participant observation. Interviews were conducted with some Heads of Administration, Head of Personnel and Human Resource Departments and Chief Executives of some government departments and agencies. As a public administration practitioner, I have had the privilege of also observing the processes of recruitment in the Federal Public service and also relating with some of the social forces that often impact on recruitment process. Some of these personal observations and experiences were sources of data for the study. Data were also gleaned from secondary sources such as textbooks and public documents.

\section{Conceptualizing Recruitment and Public Service}

\subsection{Recruitment}

The term recruitment has different connotations. At times, it is confused with selection of candidates into vacant job positions. According to Biggs (1979), recruiting and selection are often used interchangeably. However, they are closely interrelated parts of a multistage decision process. Distinguishing between the two concepts he wrote further that, while recruiting is the searching for and obtaining job candidates, selection is evaluating and deciding whether to hire candidates. This is why Williams (2012) conceived recruitment simply as the process of developing a pool of qualified applicants. He also described it as the process of finding qualified job applicants. Carrel and Kuzmits (2000) also conceived it as the process of acquiring applicants who are available and qualified to fill positions in the organization. From all the foregoing definitions, recruitment is seen as a stage in the chain of the stages involved in, employing someone in an organization. In common usage today however, recruitment is seen as getting people employed into an organization. Seen this way, therefore, it is taken as synonymous with appointment or employment. It is against this backdrop that the Nigerian Public Service Rules (2006) defined recruitment as the filling of vacancies by the appointment of person not already in the civil service of the Federal Republic of Nigeria. It, however, excludes the transfer of officers from other civil service in the federation to the Federal Civil Service. Recruitment in this context is, therefore, conceived as the whole process of getting people employed or appointed into vacant positions in the federal establishments. In the words of Coleman (1979), recruitment consists of all of the activities undertaken to advertise employment needs and to encourage qualified people to respond and also finally engaging them. (emphasis added). Coleman (1979) emphasized one point which is equally germane here and that is that, an effective recruitment process should produce the right number and the right kind of new employees at the right time and at the right place so that organizational needs can be met. On the basis of this he raised this caution: before recruitment can begin, the organization has to determine what it needs. What job is to be filled? What does that job require in terms of employee education, experience, skills, abilities and personal characteristics? If the answers to these questions are wrong, the later steps in the process can hardly be expected to produce good results. In other words, 
Coleman (1979) is of the notion that recruitment process in any organization must be scientific. Coleman (1979) raised one other fundamental point which will illuminate this discourse further and which is equally apt in closing this aspect of this work and that is that, an effective recruitment-selection process has to produce within the constraints imposed by regulations.

\subsection{Public Service}

The term public service is used to refer to all public agencies, whether their personnel affairs are managed by the Civil Service Commission or by separate governing boards, which render services to the members of the public and whose personnel are paid from public treasury. The term is used in this context to include the civil service (Ministries whose personnel are controlled by the Civil Service Commission) and other agencies listed as public service in the constitution of the Federal Republic of Nigeria namely, the security agencies; the armed forces; the National and State Assembly Services; the judiciary, parastatals and regulatory agencies; employees of educational institutions and research institutes; infrastructural agencies; statutory agencies and other service providers owned by government and established by Acts of the National Assembly and Corporations or enterprises in which government or its agency owns controlling shares or interests (Adebisi, 2014). Also as common agencies, their operations are generally guided by a single Public Service Rules.

\section{Analytical Framework}

The framework for this research is hinged on the concept of bureaucracy. Bureaucracy is chosen as a tool of analysis because the civil service and the wide spectrum of the public service are typical of large organizations to which the concept is ascribed. The choice becomes more apt granted the fact that, in his outstanding work on bureaucracy Max Weber according to Sharma,Sanda and Kaur (2012), harped on recruitment based on merit and technical qualifications, partly as the hallmarks of an effective and efficient bureaucracy which are very central to this discourse. Today, the impression the mere mention of bureaucracy creates in the minds of laymen is that of "delay", "rigidity", "excessive application of rules", "redtapism" and corruption among other pejorative connotations. As Catholic Encyclopedia, (1967) has observed in English -speaking states in Europe, it is used in derogating senses such as conness, aggressiveness, contrariness, rigidity, officiousness, timidity, caution and conservatism. It also suggests a disposition towards routine, strict procedural regularity and consistency, "red tape" or to use the more descriptive French term, "l a paperasseries". However in its pure conception the term has much deeper meaning.

According to the Catholic Encyclopedia, (1967) the term is derived from two sources. First is from the French word "bureau" which means a writing table or desk, applied by extension to any place where work desk were installed, and finally to the work itself. Second is the Greek word "Kparos", suggesting dominion or power, having a governmental or public character (p.890)

According to Hyneman, (2012) bureaucracy simply put is a word for big organization. An organization is big or bureaucratic according to him, if one has to search for finding out who 
is making its policies or its policies and procedures are written out, or if you think it takes too long for one part to find out what another part proposes to do. Blau and Mayer (2012) also conceived of bureaucracy as organization designed to accomplish large scale administrative tasks by systematically coordinating the work of many individuals. In the conception of Max Weber it is any large organizational device built on competence, division of labour and adherence to rules among other features with a view to discharging its duties in an effective and efficient manner. To him and others who share his view, the term bureaucracy is used also to designate the group of people who perform rationalized functions in large scale organizations especially governmental ones. Thus according to Encyclopedia Americana (1981) an organization is said to be bureaucratized when it procedures for action and decision have become formalized through elaborate rules that are public. This is why the government (public) service or civil service is seen more as synonymous with bureaucracy. In more specific terms, to Weber, according to Sharma, Sadana and Kaur (2012), for any entity to qualify as a bureaucracy, it must possess the following attributes: 1) Bureaucratic officials, while personally free, must discharge their official duties according to defined rules and regulations. (2) they are organized hierarchically; (3) they are selected on the basis of technical competence which may be ascertained by competitive examination or by the production of an appropriate diploma that certifies the completion of the required amount of technical training; (4) they are remunerated in money, generally through fixed salaries (5) they do not own, but use, the means of administration and production; (6) they are subject in their official actions to close supervision, discipline, and control; (7) each bureaucratic office has a clearly defined sphere of legal competence that attachés to it; (8) it is filled through individual tacit or formal contracts; (9) it is the sole or primary occupation of the incumbent; and (10) it constitutes the professional career of the functionary.

Viewed against the central focus of this paper, it implies that when recruitment is to be done into the public service, first, it must be done in accordance with defined rules and regulations. Two, public servants must be selected on the basis of technical competence. Three, the process of recruitment among other administrative tasks, must also be subject to supervision, discipline and check. Thus as a conceptual framework, bureaucracy will enable us to ascertain the extent to which public servants in Nigeria are recruited on the basis of technical competence; the extent to which rules and regulations governing the recruitment process are complied with and also the extent to which the control mechanism on the recruitment process are effective. In any event, for a close, the following facts must be brought to the front burner: one, functionally, bureaucracy is not designed to slow down the process of administration. Rather its aim is to promote impersonality and greater efficiency. Two, whatever pathologies that bureaucracy might manifest are certainly unintended. Three, the forms and the degree of the negative behavioural tendencies that bedevil a nation's bureaucracy will largely depend on its socio-political ecology.

\section{Framework of Recruitment into the Nigerian Federal Public Service}

Three essential documents provide the necessary guide for recruitment into the Nigerian federal public service. They are: the Public Service Rules (or conditions of services for parastatals and agencies) the Scheme of service and the Federal Character Commission Act. 
The general aim of these documents is to ensure that recruitment into the service is driven by competence, fairness and representativeness. Beginning with the Public Service Rules (2008) and appointment into the Federal Civil Service, Section 020101 of the PSR places the authority to appoint on the Federal Civil Service Commission. In appointing people into other Federal government bodies outside the core civil service, such authority is placed on their Governing Boards or Councils. In appointing officers on Grade Level 12-17, the Federal Civil Service Commission (FCSC) is empowered to make the appoint as the need arises into the available vacancies after advertisement. The same is required of the Governing Boards or Councils of other Federal government bodies outside the core civil service. According to Section 020102 sub-section II - V of the PSR, : (II) subject to modalities to be prescribed by the Federal Civil Service Commission from time to time, each Ministry/Extra-Ministerial Office shall select from the pooling successful candidates of the Civil Service Examination. (III) This shall be handled by the appropriate committees of each Ministry with the representatives of the Federal Civil Service Commission and Head of the Civil Service of the Federation at the meeting of the committees. (IV) There shall be an annual competitive Civil Service Entry Examination for posts graded GL 07-10 for new entrants and serving officers wishing to transfer from other scheduled services. The conduct of the examination is saddled with the Federal Civil Service Commission in conjunction with the office of the Head of the Civil Service of the Federation, Administrative Staff College of Nigeria, and the Public Service Institute of Nigeria. (V) To qualify for this examination, candidate must possess an Honours Degree or Higher National Diploma not below Upper Credit in relevant disciplines as provided for in the Scheme of Service. Final selection is to be made by the line Ministries/Extra Ministerial Offices in line with their requirements.

For appointment into junior staff positions, that is Grade Level (GL) 06 and below, the responsibility is granted to Each Ministry/Extra Ministerial Office. It is to be handled by the Junior Staff Committee of each Ministry/Office, with a representative of the Federal Civil Service Commission and the Head of the Civil Service of the Federation at any meeting of the committee, subject to the approval of the Permanent Secretary/Head of Extra Ministerial Offices.

Furthermore, appointment in the Federal Ministries/Extra-Ministerial Offices in the states shall be from the "residents" of that state who possess the qualifications prescribed in the approved Scheme of Service. (c) Each Ministry/Extra-Ministerial Office shall work out the actual establishment or requirements for each state office. The Junior Staff Committee (Local) shall conduct the interview to appoint the officers, subject to approval of the Permanent Secretary/Head of Extra-Ministerial Offices.

In bodies outside the core civil service, similar structures have been replicated to handle senior and junior Staff appointments. Across most of these extra-civil service bodies there exist Junior Staff Appointments and Promotions Committee (JSAPC) and the Senior Staff Appointments and Promotions Committees (SSAPC) which handle junior staff and senior staff appointments respectively. In carrying out these appointments, examinations and interviews are to be conducted and all the requirements for appointment as stated in the schemes of service must be met by applicants before they can be recruited. A consideration of 
a more specific example which is typical of most of the parastatals and agencies will be apt here.

According to the conditions of service of the Federal University of Technology, Akure, Ondo State, Nigeria, three Committees are responsible for the appointments of the staff of the University. They are: Appointments and Promotions Committee (Administrative \& Technical Staff), the Appointments and Promotions Committee (Academic) and the Appointments and Promotions Committee (Junior Staff). In another instance, all the Agricultural Research Institutes and Federal Colleges of Agriculture in the country under the Agricultural Research Council of Nigeria (ARCN) have their different junior staff and senior staff Appointments and Promotions Committees.

Generally speaking according to Section 020205 of the PSR (2008) to be eligible for appointment into the Federal public Service, every applicant must:

(a) Not be less than 18years and not more than 50 years of age;

(b) Possess such minimum qualification as may be specified from time to time including computer literacy.

(c) Be certified by an authorized Health Care Provider as medically fit for government service.

(d) Possess a testimonial of good conduct from the last employer or if not previously employed, from the last school or college attended, and

(e) Possess requisite qualifications as provided for in the scheme of service.

(f) Not be appointed into the Federal public Service without authorization for appointment from the office of the Head of the Civil Service of the Federation and also the supervisory Boards in the case of parastatals, and agencies.

Further still, according to Section 020206 of the PSR (2008)

(a) No candidate shall be appointed to any post in the Federal Public Service if:

(i) The candidate has been convicted of a criminal offence, or

(ii) $\mathrm{He} / \mathrm{she}$ has been previously employed in government service and been dismissed or called upon to resign or retire there from. Such approval must always be obtained.

(b) In view of Rule (a) above, every applicant for employment by Government must state:

(i) Whether he/she has been convicted of a criminal offence;

(ii) All employment he/she has engaged in; and

(a) If he/she has left employment, why he/she did so; or

(b) If he/she is still in any employment and whether he/she is under any obligation to remain in it; 
(iii) Whether he/she is free from financial embarrassment.

Apart from the above, other guides for appointment into the Federal Public Service include:

(a) Abolition of all forms of temporary appointment which were used to be made at the pleasure of the Chief Executive of Federal agencies. This is because it was being abused by many Chief Executives as they engaged their friends, relatives and cronies to the disadvantage of many.

(b) Abolition of appointment of persons with higher qualifications into a junior position.

This is of course a correct provision as GreenLaw and Biggs (1979) have written, that, the aim of an organization should be to avoid hiring of both; (1) under qualified individual who will likely experience frustration on the job and who may have to be terminated by the organization (2) over qualified individuals who will not have an opportunity to utilize fully their abilities and hence also experience frustration.

(c) Possession of a certificate signed by the chairman or secretary of his/she Local Government indicating his/her state of origin and Local Government Area;

(d) Possession of the National Youth Service Corps discharge or exemption or exclusion certificate where applicable.

(e) As for the core civil service, Section 160302 of the PSR (2008) also stresses that, appointments into all grades in parastatals shall be need-based and subject to the approval of the supervisory Boards/Councils. The Section stresses further that, such appointments shall be made through as fair and open selection process that ensures merit, credibility and equal employment opportunity for all with due regard to the Federal Character Principle.

The second vital document that provides guide for appointment into the Federal public service is the Scheme of Service. In simple terms, it can be defined as government approved document which contains the requirements for appointments and promotions to different approved positions or posts in the Federal Public Service. The core civil service has its own scheme of service and every other Government parastatal or agency has its own scheme of service peculiar to its manpower needs. Essentially, a Scheme of Service has the following properties: One, it contains all the recognized posts or cadres in an establishment. The implication of this is that, the establishment can only appoint candidates into only positions recognized by the scheme of service. Furthermore, it also implies that if a position does not exist in the Scheme of Service of an establishment, the establishment can not recruit into such post on the strength of the existence of the post in the scheme of service of another establishment

Two, it states the method of entry and advancement within the cadre. For example, in Agricultural Research Institutes, the entry requirements and advancement within the cadre of Research officer are clearly stated. To be sure, in order to enter the cadre as Research officer II, the scheme of service states that: by appointment of a holder of a good honours degree, not below Second Class Upper with NYSC discharge certificate. 
Three, a scheme of service will also state the minimum entry position to a cadre and also the peak of the cadre.

Four, the salary attached to every position is also stated.

Five, the method(s) of converting from one cadre to another is also often expressed in the scheme of service.

Six, the scheme of service outlines the duties attached to each positions or states.

Seven, scheme of service must be approved by Government after it must have been developed by the relevant stakeholders.

It should be noted that scheme of service can be reviewed from time to time through occasional government circulars or during a general review.

Another vital official document that guides appointment into the Federal Public service is the Federal Character Commission Act. The Act seeks to ensure that all appointments into the Federal Public Service and the State Public Service reflect the federal character of the country. More specifically, the Federal Character Commission is mandated by paragraphs 8(1) (a) and (b) of Section C, part I, Third Schedule to the 1999 Constitution of the Federal Republic of Nigeria to:

(a) Work out an equitable formula subject to the approval of the National Assembly for the distribution of all cadres of posts in the public service of the Federation and of the states, the armed forces of the federation, the Nigeria Police Force and other government security agencies, government owned companies and parastatals of the states;

(b) Promote, monitor and enforce compliance with the principles of proportional sharing of all bureaucratic, economic, media and political posts at all levels of government;

(c) Take such legal measures including the prosecution of the head or staff of any Ministry or government body or agency which fails to comply with any federal character principle or formula prescribed or adopted by the commission;

Furthermore, Section 8(2) provides that, the posts mentioned in sub-paragraph (1)a and (b) of this paragraph shall include those of the Permanent Secretaries, Director-General in Extra-Ministerial Departments and parastatals, Directors in Ministries and Extra-Ministerial Departments; senior military officers, senior diplomatic posts and managerial cadres in the Federal and State parastatals, bodies, agencies and institutions. Section (3) stresses, that, not withstanding any provision in any other law of enactment, the Commission shall ensure that every public company or corporation reflects the federal character in the appointments of its directors and senior management staff.

The subsidiary legislation of the Commission further provides the guiding principles and formulae for the distribution of all cadres of posts. These include that: 
(1) Each state of the federation and the federal capital Territory shall be equitably represented in all national institutions and in public enterprises and organizations.

(2) The best and most competent persons shall be recruited from each state of the federation to fill positions reserved for the indigenes of that state or the Federal Capital Territory.

(3) Once a candidate has attained the necessary minimum requirement for appointment to a position, he shall qualify to fill a relevant vacancy reserved for indigenes of his state or the Federal Capital Territory.

(4) Where the number of positions available cannot go round the states of the federation and the Federal Capital, the distribution shall be on zonal basis but in the case where two positions are available, the positions shall be shared between the northern and the southern zones.

(5) Where the indigenes of a state or the Federal Capital Territory are not able to take up all the vacancies meant for them, the indigenes of any other state(s) or the Federal Capital Territory within the same zone shall be given preference in filling such vacancies. Provided that where the zone to which the preference is given fails to take up such vacancy the indigenes from any other zone shall be considered for the appointment.

(6) Each state shall produce 2.75 percent of the total work force in any Federal establishment while the federal capital Territory shall produce 1 percent for the indigenes of the Federal Capital Territory provided that the Commission may adopt a range so that the indigenes of any state of the Federation shall not constitute less than the lower limit or more than the upper limit of the range as set out in paragraph 12 (a).

(7) In the case of distribution on zonal basis the Commission shall adopt another range such that the indigenes of a particular zone shall not constitute less than the lower limit or more than the upper limit of the range as set out in paragraph 12(b).

For this purpose the country is divided into six geopolitical zones.

(8) Depending on the number of states within each zone, the Commission according to its Handbook (2011) shall adopt three ranges such that the indigenes of any state within a zone shall not constitute less than the lower limit or more than the upper limit of the range applicable to the zone as set out in paragraph 12(c).

In Part III on application of partial principles, the following provisions are also to guide appointments into the federal public service especially for career posts:

(a) The indigenes of a state of the federation shall constitute not less than 25 percent or more than 3 percent of all officers including a junior staff of the head offices of any national institution, public enterprise or organization. In the case of branches or local offices, not less than 75 per cent of these categories of staff shall be indigenes of the catchment area; 
(b) Where the number of vacancies are not sufficient to go round the 36 states of the federation and the FCT, the vacancies shall be shared among the zones such that the indigenes of a particular zone shall not constitute less than 15 percent or more than 18 percent;

(c) Within a zone, the indigenes of a particular state shall not constitute less than 12 percent or more than 15 percent in the case of North Central and North West; not less than 15 percent or more than 18 percent in the cases of North East, South South and south West; and not less than 18 percent or more than 22 percent in the case of South West.

In exercising its power to evolve formula for ensuring the reflection of Federal Character in appointments into federal establishments, the Commission has also formulated the template for recruitment into the Federal Public Service. The key steps are:

(a) Each MDA shall ensure proper manpower planning in accordance with its authorized staffing/manning level;

(b) When there is need to recruit staff, available vacancies shall be harvested and identified cadre by cadre;

(c) The spread of all vacancies to be filled shall be predetermined in relation to current levels of (Federal Character) representation, by States or geo-political zones, at a joint meeting of the recruiting MDA and the FCC;

(d) The MDA shall ensure and provide comprehensive job description (academic qualifications and cognate experience) required for each vacant position.

(e) All vacancies shall be advertised in at least two newspapers circulating nationally, giving prospective candidates a minimum of six weeks within which to apply.

(f) In filling the allotted vacancies, adequate consideration shall be given to gender representation and the physically challenged;

(g) Where candidates are required to apply on-line, hand copies of such applications shall nevertheless be accepted.

(h) In the event of candidates being required to buy scratch cards, the cost shall not be more than one thousand naira only.

(i) Where the services of consultant are engaged by any employer of labor in the Federal Public Service, it shall be the duty of such MDA to acquaint the consultants with the process outlined herein for strict compliance. The consultants shall disclose, in the advertisement, the MDA on which behalf they acting (sic) responsibility for such compliance shall lie with the MDA.

Other provisions in the circular as published in the Handbook (2011) are that:

(1) Only candidates who have met the basic minimum requirement for each position shall be short-listed for written tests/oral interview or any other selection process. Under no circumstance shall an unqualified candidate be short-listed purportedly on the basis of 
Federal Character consideration. However, a candidate who has met the basis (sic) minimum requirements shall be eligible to compete for posts reserved for his state and/or zone, and shall not be penalized or disadvantaged in favour of a candidate from another state or zone who may possess higher qualification.

(2) At the close of advertisement, and from the long list of all applications received, a shortlist of qualified candidates shall be compiled for interview or any other mode of selection on state by state basis.

(3) The shortlist must be drawn as much as possible, in equal number, from each state of the Federation and approximately a third of that number from the FCT, indicating also, the Local Government area of origin. (Where an aptitude test or any other type of written or oral test is required as part of the selection process, the compilation of results shall be on state by state basis, in order to enable (sic) the best candidates from each state and the FCT to be employed).

(4) The best and most competent candidates from each state of the federation and the FCT shall be short-listed to compete for positions reserved for their respective states/zones.

(5) The list of successful candidates shall be compiled and at a special joint meeting of the MDA and FCC, matched, for consistency, with pre-determined distribution formulae.

(6) In compiling the list of successful candidates for employment from a state, the recruiting MDA shall ensure that there is a fair and equitable spread amongst indigenes of the Local Government Areas of the State or the Senatorial Districts.

(7) A certificate of compliance (with the FCC (principles/guide-lines shall be issued as final authorized for the release of letters of appointment to successful candidates by the recruiting MDA. In other words, on MDA should issue Letters of Appointment to candidates without this certificate.

To further prevent arbitrariness, the law also provides that:

In view of the fact that the appointment of temporary, casual, oral contract staff (by whatsoever name called) can have adverse effect on the staff distribution pattern of an MDA, such appointments should only be carried out sparingly subject always to prior written approval of the Commission.

The letters of appointment are expected to be issued within three months otherwise the certificate of compliance shall become in operative and shall require revalidation by the Commission.

The Act establishing the Commission also provides for the prosecution of the Head of the MDA that breaches the Act and the procedures laid down by the Commission in carrying out recruitment exercise in the federal public service.

From the foregoing, the following points come to the fore: one, there is deliberate attempt by 
the Nigerian state to ensure that the federal bureaucracies reflect the diversity of the country. Two, it also aims at equitable distribution of posts and federal resources. Three, theoretically, it still places premium on merit as opposed to the wide belief that the federal character principle does not allow for merit.

Other adjunct official pronouncements which are to be guiding public service recruitment at the federal level include: gender balancing; the need to give opportunities for those that are physically challenged and non-discrimination against those with some health challenges such as HIVs/AIDS. In sum, let it be stressed that: first, there are enough administrative safeguards to prevent arbitrary recruitment into the federal public service. Two, there are adequate mechanisms engineered through the scheme of service to ensure that the Weberian principles of technical qualification and merit inform appointments into the federal public service. Three, the Nigerian state is desirous of effective and efficient bureaucracies without compromising their representativeness. Finally, the system is responsive to gender and the needs of the physically challenged and others with challenging health issues.

\section{Constraints on Recruitment into the Federal Public Service}

In as much as the recruitment mechanism instituted at the federal level aspires to fairness, competence and representativeness, this research has discovered that the drivers of the mechanism are faced with a number of social pressures or constraints which have made the attainment of the ideals difficult. Some of these pressures or constraints are exogenous to the federal establishments while some are endogenous to them.

\subsection{Exogenous Constraints}

From the earlier discussion of the framework for recruitment into the federal public service, it can be inferred that, for any federal agency to recruit, the following federal authorities have key roles to play: the Office of the Head of service of the Federation (to approve the vacancies declared and give authority to recruit); the Budget office (to ensure that the approved vacancies are captured in the Budget for the year in which the recruitment is to be done) and the Federal Character Commission (to observe recruitment process and ensure compliance with the federal character principle). Added to this is the fact that the National Assembly has to approve the Budget for a year including the personnel cost estimates by every federal agency. The reality is that all these agencies in this chain of recruitment mount pressure on the Chief Executives of the recruiting agencies with a view to employing their candidates which may be their children, relations, friends, townsmen and women, members of the constituencies of the legislators or even buyers of employment or jobs. Practically, the pressure flows like this: at the Office of Head of Service, the Chief Executive may have to secretly promise some authorizing officers some vacancies before he can get the approval to recruit. The Budget office officials may make similar secret demand promising to capture the appointments in the budget or threatening not to capture it in the budget if not granted concession; the Federal Character Commission officials may make similar demand with the bait that it will grant the recruiting agency waiver not to advertise. Further still, the members of the National Assembly who in most cases had sent their requests to the recruiting agency for preferential appointment, may also seek to exert some concessions from the recruiting 
agency before its personnel budget is passed. For instance, a federal legislator had written to the Chief Executive of a federal organization for assistance thus: "I wish to recommend the underlisted candidates for employment in your reputable organization. He is from my constituency and 1 am confident he will be a good asset to the growth of your organization" (Olamide, J., personal communication, 7th October, 2016).

Apart from these bureaucratic and political pressures, the recruiting agency still on the other hand has to accommodate exogenous pressures from the traditional rulers of the Chief Executive's home town, the leaders and members of the community in which the establishment is located; his church or mosque leaders and members; his cronies, in-laws, old school mates, and the alumni of the establishment if it is a tertiary educational institution. A letter of request from a traditional ruler requesting for employment assistance from a Chief Executive of an organization reads thus: Greetings from the ancient throne of the....and paramount Ruler of...Land, His Imperial Majesty... The below (sic) are the names of some of the applicants seeking employment and I am forwarding their names... to you for your consideration and necessary action please... ( Aladetoyinbo, O., personal communication, $5^{\text {th }}$ April, 2016)

\subsection{Endogenous Constraints}

Apart from the exogenous forces highlighted above, federal government owned recruiting agencies are also confronted with internal pressures. These endogenous pressures come from the Governing Boards or Councils of the agencies; their Internal Management Committees; the Principal Officers of the agencies; the trade union leaders within the agencies; members of the kitchen cabinet and cronies of the Heads or Chief Executives of the agencies.

The implications of all these pressures are these: one, there is the possibility that advertisement may not be placed as such recruitment may not be openly and transparently conducted. Two, if advertisement is placed, there is also the possibility the out-come of the recruitment exercise would have been largely pre-determined and skewed in favour of people coming from the above identified loci of pressures. Three, in the face of these intimidating pressures, there is the possibility of recruiting people that are not qualified, less qualified, with irrelevant qualifications and with unimpressive and inappropriate records of appointment. In this process merit and competence will be sacrificed. Four, the principle of federal character will apparently be violated. Indeed, consequent upon this trend, this research discovered organizations in the country whose workforces were dominated by people from the same town or state or even families thereby granting people from other states extremely low representation. Exogenous and endogenous pressures have indeed created a situation where father, mother, son and in-laws of the Chief Executives, Principal Officers and friends of the Chief Executives glaringly dotted many federal agencies to the deprivation of the children of the ordinary masses who are not well-connected. Five, there is also the possibility that vacancies are approved, budget is created for the vacancies and money is eventually appropriated not on the basis of the manpower need of the organization, but on the basis of the imperativeness of meeting these contending interests. The cumulative effect of this is over bloated manpower and redundancy with their attendant challenges of ineffectiveness and inefficiency. 


\section{Agenda for Reform}

As the Federal public service has been found to be ineffective and inefficient partly on account of recruitment malpractices largely precipitated by the constraints highlighted above, it is imperative that the recruitment process be reformed. To this end, the following items are proposed as the agenda for the reform:

1. There is the need to embark on regular re-orientation of officials of all the agencies that are involved in the chain of recruitment in the Federal public service on the need to have merit driven service and representative bureaucracy. This will go along way in minimizing large scale arbitrariness that has permeated recruitment process in the service.

2. The federal government should deploy intelligence gathering mechanism to crack down on syndicate groups that engage in sale of appointments in the Federal public service. When arrested, such officers should be punished appropriately to serve as deterrent to others.

3. Government should abolish the authority of the Federal Character Commission to grant waiver not to advertise some vacancies that are few in number and require urgency to fill. This is because a lot of abuses have been perpetrated under the guise of this waiver authority.

4. The Federal Government should also from time to time audit recruitment processes in federal agencies using external Audit Committee. Where infractions are discovered sanctions should be imposed appropriately. This will go a long away in stemming the tide of abuses.

5. A Bureau to be known as Bureau of Employment Monitoring (BEMO) to be domiciled in the Presidency should be set up. It should among other oversight functions be saddled with the following responsibilities.

(a) Serving as a data bank or warehouse for all approved vacancies in all federal government agencies.

(b) Publishing a journal in which all federal agencies must advertise all approved vacancies every year.

(c) Receiving quarterly or annual reports on recruitment exercise from all federal establishments.

(d) Correcting and recommending erring federal agencies to the appropriate authority for disciplinary action(s).

(e) Raising External Audit Committee for the monitoring of appointments in all federal agencies on annual basis or upon receipt of complaints from members of public.

(f) Receiving and investigating complaints or petitions from members of the Public on recruitment in all federal establishments. 
6. It has also been observed that the current pressure on the recruitment process in the Federal public service has been largely due to shrinking job opportunities in the private sector of the Nigerian economy. Adjunct to this reform agenda therefore is the need for the Nigerian government to reform the Nigerian economy with a view to reviving sectors such as banking, mining, manufacturing, agriculture, transport, and energy among others and thereby creating more job opportunities in the sectors. With better and greater opportunities in the private sector, the present kind of pressure on the public service will be deflated. In other words, if there is job security in the private sector, if the pay is equally good and both sectors run the same contributory pension scheme, there will be less pressure on the public service recruitment process.

\section{Conclusion}

There is no doubt that the recruitment process into the Nigerian Federal Public Service has been bedeviled by a lot of social, administrative and political constraints. These constraints have engendered not only exclusiveness in the composition of the Federal Public Service and thrown up inefficiency, ineffectiveness and low productivity, but have also overthrown merit and competence as advocated by Max Weber. A reformed recruitment process cast in the mode of the above Reform Agenda, will go along way in getting closer to Weber's bureaucratic ideals and instituting a public service that will be highly responsive to the needs of the people.

\section{References}

Adebayo, A. (2004). Principles and Practice of Public Administration in Nigeria, Ibadan: Spectrum Books Ltd.

Adebisi, P. A. (2014). "The Reform of the Nigerian Public Service". In Ayoade, A. A., Akinsanya, A. A., \& Ojo, O. J. B. (Eds).The Jonathan Presidency: The Sophomore Year, Ibadan: John Archers.

Agricultural Research Council of Nigeria. (2009) Approved Guidelines for the Management of Agricultural Research Institute and Federal Colleges of Agriculture, Abuja: ARCN.

Akande, A. A. (2000). Fresh start in Osun State, Osogbo: Osun State Government Press.

Coleman, C. J. (1979). Personnel: An Open System Approach, Massachusetts: Winthrop Publishers, Inc.

Correll, M. R., \& Kuzmits, F. E. (1981). Personal Human Resource Management $2^{\text {nd }}$ Ed., Columbus, Ohio: Mervill Publishing Company.

Denhardt, R. B., \& Denhardt, J. (2009). Public Administration An Action Orientation sixth edition, Belmont: Thomson Wadswoth.

Federal Character Commission. (2011). Federal Character Monitor. 20 ${ }^{\text {th }}$ Edition, Abuja, Federal Government Press.

Federal Character Commission. (2011). Handbook, Abuja: Federal Government Press. 


\section{Macrothink}

Journal of Public Administration and Governance

ISSN 2161-7104

2017, Vol. 7, No. 4

Federal Character Commission. (2012). Federal Character Monitor,Third and Fourth Quarters, Abuja; Federal Government Press.

Federal Civil Service Commission. (2008). Guideline for Appointments, Promotions and Discipline, Abuja: Federal Government Press

Federal Republic of Nigeria. (2004). Schemes of Service for Federal Research Institutes, Colleges of Agriculture and Allied Institutions, Abuja: Federal Government Press.

Federal University of Technology Akure. (2003). Calendar 2003-2005, Akure, Wurakay.

Greenlaw, P. S., \& Biggs, W. D. (1979). Modern Personnel Management, Philadelphia: W.B. Saunders Company.

Hyneman, C. (1960) Bureaucracy and Democratic System, New Delh, Oxford and IBH Publishing Co.

New Catholic Encyclopedia. (1967). New York: McGraw-Hill Book Company.

Peter, M. B., \& Mayer, M. W. (1966), Bureaucracy in the Modern Society, New York, Prentice Hall.

Shama, M. P., Sadana, B. L., \& Kaur, H. (2012). Public Administrationin Theory and Practice. Allahabad: Kitab Mahal.

The Encyclopedia Americana. (1981), Danbury: Grolier Incorporated

The Federal Government of Nigeria (2008). Public Service Rules. Lagos: The Federal Government Press.

The Federal Government of Nigeria. (2006). Public Services Rules, Lagos: Federal Government Press.

The Federal University of Technology, Akure. (2011). Reviewed Scheme of Service of Employees on Contiss 06 and Above in the University, Akure, Wurakay

The Nigerian Constitutions, a Compendium - 1963, 1979 \& 1999 (1999), Efon-Alaaye: Landlords Publication.

The Punch. (2017). Lagos, August 30.

The Work Bank Encyclopedia. (2001). Chicago: World Book Inc.

Williams, C. (2012). Effective Management, A Multimedia Approach. United States: South-Western Cengage Learning.s.

\section{Copyright Disclaimer}

Copyright for this article is retained by the author(s), with first publication rights granted to the journal.

This is an open-access article distributed under the terms and conditions of the Creative Commons Attribution license (http://creativecommons.org/licenses/by/4.0/). 